\title{
Self-Efficacy, Family Support and Toothbrushing Practice of Primary School Students
}

\author{
Hermien Nugraheni ${ }^{1)}$, Aryadiva N.Prayoga ${ }^{2)}$, Raaufa Imaria Nurjati ${ }^{1)}$ \\ (hermienprajoga@gmail.com,divaprayoga988@gmail.com,rraaufa@gmail.com) \\ ${ }^{1}$ Poltekkes Kemenkes Semarang \\ ${ }^{2}$ Aisyiyah University Yogyakarta
}

\begin{abstract}
School age is a critical period because at this time children begin to develop the habit of maintaining oral hygiene. The purpose of this study was to prove the relationship between self-efficacy and family support for toothbrushing practice of elementary school students. The population in this study was fifth grade students of primary schools. Measuring instruments used were the Self-Efficiency Scale, the Family Social Support Scale and the Teeth Brushing Scale. Data analysis showed that the double correlation coefficient between self-efficacy and family social support with tooth brushing was $\mathrm{R}=$ 0.837 with a significance level of $0,000(p<0.01)$. Self-efficacy and family social support have a very significant relationship with the toothbrushing practice. The higher the self-efficacy and the higher the family's social support, the better the toothbrushing practice.
\end{abstract}

Keywords: Self-Efficacy, Family Support, Toothbrushing

\section{Introduction}

School age is an important age in a child's physical growth and development. This period is also referred to as a critical period because at this time children begin to develop habits that usually tend to persist into adulthood. One of them is the habit of maintaining oral hygiene. The behavior of Indonesian children in maintaining oral health is still low. ${ }^{(1)}$ Dental care is considered not too important, even though the benefits are very vital in supporting health and appearance. These behaviors arise due to the lack of knowledge of children about the importance of oral health care, so they neglect oral hygiene. ${ }^{(2)}$ This is the cause of oral health problems that often occur in school-age children. The results of Basic Health Research (Riskesdas) in 2018 showed that the prevalence of children experiencing oral and dental health problems based on age characteristics was 5-9 years at $21.6 \%$, and $10-14$ years at $20.6 \%$. ${ }^{(3)}$ The results of Riskesdas 2018 also mentioned that only $2.7 \%$ of Indonesia's population had done the right toothbrushing, correct in the sense of being on time, on the right tools and on the right way. ${ }^{(3)}$ In social cognitive theory there are three things that affect a person so that he can do the right toothbrushing practice, namely individu, behavior and environment. ${ }^{(4)}$ Student factors include knowledge, goals to be achieved, metacognition abilities and self-efficacy. Behavioral factors include behavior self reaction, personal self reaction and environment self reaction. While environmental factors can be in the form of physical or social environment, 
both family environment, school environment, social environment, etc. ${ }^{(5,6)}$ One of that can influence the toothbrushing practice's student factors is self-efficacy and environmental factors include family social support.

Self-efficacy is a student's belief about his ability to organize and complete a task that is needed to achieve a certain result. Self-efficacy is the belief that someone can master the situation and get positive results. ${ }^{(7,8)}$ Self-efficacy has a big influence on behavior. For example, a student who has low self-efficacy will not want to try to do the right toothbrushing because he does not believe that the right toothbrushing will prevent cavities that cause pain. Several dimensions of self-efficacy, namely magnitude, generality, and strength. Magnitude, related to the level of difficulty of a task performed. Generality, related to the field of assignment, how broad students have confidence in carrying out tasks. Strength, related to the strength or weakness of a student's beliefs..$^{(9,10)}$

Self-efficacy can be obtained, modified, enhanced or reduced, through one or a combination of four sources, namely the experience of mastering performance achievements, vicarious experiences, social persuasion and emotional arousal (emotional/physiological states). ${ }^{(9,11)}$ Performance experience is an achievement that has been achieved in the past. Vicarius experience is gained through social models. Social persuasion is trust in the person giving the persuasion, and the realistic nature of what is persuaded. ${ }^{(12)}$

Self-efficacy is thought to affect the toothbrushing practice. People who have high selfefficacy, will have confidence about their ability to do something to achieve certain results in various forms and levels of difficulty, so that the ability to perform certain actions is also high. ${ }^{(7.13)}$ Low self-efficacy will greatly affect a person in completing their assignments to achieve certain results. ${ }^{(14)}$ This can be attributed to the lack of information about the ability of students to believe in themselves in performing the correct toothbrushing practice.

In addition to self-efficacy, another factor that is thought to influence toothbrushing is social support. Social support is included as an environmental factor. Social support is physical and psychological comfort provided by friends / family members. Social support can also be seen from the number of social contacts that occur or are made by students in establishing relationships with resources in the environment. ${ }^{(15,16)}$ This research emphasizes more on social support that comes from families. There are four aspects of social support, namely, emotional support, appreciation, instrumental, and informative. ${ }^{(5,17)}$ Social support comes from significant others who are close to (significant others) for students who need help, for example in schools such as teachers and peers. ${ }^{(18,19)}$ The author emphasizes family social support which will influence the daily action of children's toothbrushing.

The purpose of this study was to prove the existence of association between self-efficacy and family support for elementary school student toothbrushing practice.

\section{Method}

The population in this study were fifth grade elementary school students in the working area of Kedungmundu Health Center Semarang City, aged 10-12 years, totaling 900 children. The sampling technique uses cluster random sampling and 90 students are selected from 3 classes as a research sample.

Measuring instruments used in this research are Self-Efficacy Scale, Family Social Support Scale and Toothbrushing Scale. Toothbrushing practice scale consists of 15 items. The SelfEfficiency Scale numbered 15 items and was arranged based on the theory of self-efficacy 
dimensions proposed by Bandura (1997), namely magnitude, generality, and strength. The Family Social Support Scale is 10 items and is arranged using theory consisting of aspects of emotional support, appreciation, information and instruments.

\section{Result and Discussion}

Research data included data on toothbrushing practice, self-efficacy data and family social support data. Samples taken in this study were 90 subject fifth grade elementary school students in the working area of the Kedungmundu Health Center.

Table 1. Univariate data on toothbrushing variables, self-efficacy data and family social support data

\begin{tabular}{llr}
\hline No & \multicolumn{1}{c}{ Variable } & Frequency $(\%)$ \\
\hline 1 & Toothbrushing practice & \\
& Poor & 3,23 \\
& Enaugh & 80,65 \\
& Good & 16,13 \\
2 & Self-Efficacy & \\
& Low & 3,23 \\
& Moderate & 67,74 \\
& High & 29,03 \\
3 & Family social support & \\
& Low & 1,61 \\
& Average & 51,61 \\
& High & 46,77 \\
\hline
\end{tabular}

Based on the results of categorizing the scores of the tooth brushing variables, the majority $(80.65 \%)$ of the research subjects were in the moderate category. While self-efficacy brushing teeth variable, most $(67.74 \%)$ research subjects were in the medium category and in the family social support variable, most (51.61\%) research subjects were in the moderate category.

Table 2. The relationship between tooth brushing variable, self-efficacy of brushing teeth and family social support

\begin{tabular}{llcc}
\hline No & Variable & \multicolumn{2}{c}{ tooth brushing practice } \\
& & Multiple Correlation Coeficient & Significance level \\
\hline 1 & self-efficacy of brushing teeth & $\mathrm{R}=0,837$ & $0,000(\mathrm{p}<0,01)$ \\
2 & family social support & & \\
\hline
\end{tabular}

The results of data analysis showed that the multiple correlation coefficient between selfefficacy and family social support with tooth brushing practice was $\mathrm{R}=0.837$ with a significance level of $0,000(p<0.01)$. These results indicate that self-efficacy and family social support have a very significant relationship with the teethbrushing practice. Based on the results of this study it can be seen that there are two internal factors (in students) that determine or influence the teethbrushing practice, were self-efficacy and family social support.

Self-efficacy and family social support make an effective contribution to the teethbrushing practice or a determinant coefficient (r2) of 0.700 meaning that there is a $70 \%$ effect of selfefficacy and family social support on the teethbrushing practice. This means that there are 
$30 \%$ other variables besides self-efficacy and family social support that affect toothbrushing besides self-efficacy and family social support.

Table 3. The relationship between tooth brushing and self-efficacy of brushing teeth variables

\begin{tabular}{ccc}
\hline Variabel & \multicolumn{2}{c}{ tooth brushing practice } \\
& Correlation Coeficient & Significance level \\
\hline self-efficacy of brushing teeth & $\mathrm{r}=0,836$ & $0,000(\mathrm{p}<0,01)$ \\
\hline
\end{tabular}

The results of the analysis (product moment) between self-efficacy variables with tooth brushing practice showed the correlation coefficient was $r=0,836$ with a significance level of $0,000(\mathrm{p}<0.01)$ which means that the higher the self-efficacy then the teeth brushing practice get better and the lower the self-efficacy the teeth brushing practice get worse.

Table 4. The relationship between tooth brushing and family social support variables

\begin{tabular}{ccc}
\hline Variable & \multicolumn{2}{c}{ tooth brushing practice } \\
& Correlation Coeficient & Significance level \\
\hline family social support & $\mathrm{r}=0,418$ & $0,002(\mathrm{p}<0,01)$ \\
\hline
\end{tabular}

Furthermore, the results of the analysis of family social support with tooth brushing showed that the correlation coefficient between tooth brushing and family social support was $r$ $=0.418$ with a significance level of $p=0.002(p<0.01)$ which means that the higher the family social support then the teeth brushing practice are getting better, and the lower the family's social support, the teeth brushing practice are worse.

Subjects categorization showed that most of the research subjects $(80.65 \%)$ had moderate levels of tooth brushing. This shows that in general the subjects have enough ability to actively manage themselves to gain knowledge about the importance and how to brush their teeth properly. This is because students use their ability to learn, although not yet optimally. This can be caused by students' knowledge that is more and more diverse, there are high targets to be achieved, and there is social support from those closest to him. ${ }^{(20)}$

Self-efficacy categorization shows that most of the research subjects $(67.74 \%)$ have moderate level of self-efficacy for tooth brushing. This shows that in general the subjects have enough confidence about their ability to brush their teeth to reach their goals and overcome obstacles. Students who have confidence about their abilities can be caused by students working harder and diligently in doing the right brushing in the midst of difficulties. ${ }^{(21)}$ Students prefer to do it themselves without the help of others. In addition, students observe the success of others who have the same abilities and advice from those closest to them. And high spirits to prevent the threat of cavities.

The categorization of family social support shows that the majority of research subjects $(51.61 \%)$ have moderate family social support. While $46.77 \%$ of research subjects have high family social support. This shows that in general the subject received social support which tended to be high from his family. Social support that tends to be high from the family can be caused by students getting warmth, attention, encouragement, direction, and guidance from the family, if the student concerned is experiencing dental health problems. Meeting the needs of correct tooth brushing practice that support student activities to maintain clean teeth and praise if the student concerned gets an achievement. ${ }^{(22,23)}$ Self-efficacy is a cognitive process that affects a person's motivation to behave. How well someone can determine or ensure the fulfillment of the motives leads to the expected actions according to the situation at hand. 
Confidence in all of these abilities includes self-confidence, ability to adapt, cognitive abilities, intelligence, and motivation to act in stressful situations. ${ }^{(21)}$ Self-efficacy will gradually develop in line with increasing ability and increasing experiences. ${ }^{(24)}$ This selfefficacy determines how much confidence there is in the ability of each student to do the right brushing so that they can achieve optimal dental and oral health results. Students who have high self-efficacy will set themselves well to brush their teeth. There is a belief in him that he will be able to complete any difficult action when brushing his teeth, the belief that he is able to complete a variety of clean and healthy behaviors and strive to do so. ${ }^{(7,17,18)}$ This will encourage students to be able to plan brushing his teeth, trying to monitor and manipulating the environment in such a way as to support his brushing activities. Thus it can be seen if the student's self-efficacy is low, it can cause obstacles in the process of brushing his teeth even though the student has great potential. ${ }^{(7.25)}$ High self-efficacy leads to the emergence of high brushing.

Other internal factors that are able to influence the tooth brushing practice are family social support which has an important role because the family is the closest person to the student. If students get emotional support from their families, when facing obstacles in doing the right brushing action, the child will get support from his family so that he still feels more confident and is still able to plan and control the right tooth brushing practice and make use of his environment. ${ }^{(22,23)}$ When a child is given positive support, for example in the form of praise from his family the child will feel he is quite valuable so that when he does the right brushing he has the urge to regulate and monitor his brushing activities and to select a conducive environment for correct teeth brushing. Information support provided by the family will also help children to get good information about how to brush their teeth properly. While support in the form of material / instrumental can be seen from parents who are trying to prepare the correct teeth brushing equipment and tools for children, so that children have the motivation to prepare and regulate their tooth brushing activities and make use of their environment so that they can brush their teeth effectively. ${ }^{(26,27)}$ It can be concluded that the higher the social support provided by the family, the better the tooth brushing practice.

If both factors, namely self-efficacy and family social support are owned by students, both of them together will be able to improve one's tooth brushing actions. Because students' motivation to plan, monitor and control their toothbrushing activities arises from internal and external motivations.

Students who have high self-efficacy will have confidence when brushing their teeth including difficulty in fulfilling aspects of the right time, the right tools and the right way. ${ }^{(24)}$ Low self-efficacy will also greatly affect a person in doing the right brushing action. This can be attributed to the lack of information about the ability of students to believe in themselves in a clean and healthy life behavior, in this case the behavior of maintaining dental hygiene. ${ }^{(28)}$

If the social support from the family received by the student concerned is low, this can hamper the ability of students to do the right brushing. High social support from his family will increase the correct action of brushing his teeth. People who get high family social support will get a lot of emotional support, appreciation, instrumental, and informative from the family. If emotional support is high, students will get high motivation from family members. If the award for the student is large, it will get praise. If students get instruments, they will get adequate facilities from the family. If students get enough information, they will get advice so that students become more confident. This results in the students' brushing action being high because students are able to effectively manage their own toothbrushing experience in various ways so as to achieve optimal results. 


\section{Conclusion}

1. Self-efficacy and family social support have a very significant relationship with the toothbrushing practice. Self-efficacy and family social support make an effective contribution to the toothbrushing practice, there is a $70 \%$ influence of self-efficacy and family social support on correct toothbrushing practice. This means that there are $30 \%$ other variables besides self-efficacy and family social support that affect toothbrushing besides self-efficacy and family social support.

2. The higher the self-efficacy the better the toothbrushing practice and the lower the selfefficacy the worse the toothbrushing practice.

3. The higher the family's social support, the better the toothbrushing practice, and the lower the family's social support, the worse the toothbrushing practice.

\section{Acknowledgments}

The researcher presents his sincere appreciation goes to Mr. Marsum, BE, S.Pd, MHP as the director of Health Polytechnic Ministry of Health Semarang. Also this research would not have been possible without the help, support and patience of our reviewer, Dr. drg. Lanny Sunarjo, MDSc, and Dr. drg. Diyah Fatmasari, MDSc, for her supervision, advice, and guidance from the very early stage of this research as well as giving me extraordinary experiences throughout the past few years.

\section{References}

[1] Hamdalah A. Efektivitas Media Cerita Bergambar dan Ular Tangga dalam Pendidikan Kesehatan Gigi dan Mulut Siswa SDN 2 Patrang Kabupaten Jember. J Promkes. 2013;1(2):118-23.

[2] Reddy M, Singh S. Viability in delivering oral health promotion activities within the Health Promoting Schools Initiative in KwaZulu-Natal. SAJCH South African J Child Heal. 2015;9(3):93-7.

[3] Balitbangkes Kemenkes RI. Hasil Utama Riskesdas 2018. 2018. 88 p.

[4] Scherr RE, Linnell JD, Dharmar M, Beccarelli LM, Bergman JJ, Briggs M, et al. A Multicomponent, School-Based Intervention, the Shaping Healthy Choices Program, Improves Nutrition-Related Outcomes. J Nutr Educ Behav [Internet]. Elsevier Inc.; 2017;49(5):368379.e1. Available from: http://dx.doi.org/10.1016/j.jneb.2016.12.007

[5] Fitzgerald A, Kelly CN, Nixon E, Shevlin M. Self-Efficacy for Healthy Eating and Peer Support for Unhealthy Eating Are Associated with Adolescents â€TM Food Intake ... Appetite [Internet]. 2013;63:48-58. Available from: http://dx.doi.org/10.1016/j.appet.2012.12.011

[6] Stats B, Posts T. Health Promotion. Australian Nursing Journal. 2012. 2011-2013 p.

[7] Woodall J, Woodward J, Witty K, Mcculloch S. An Evaluation of Calderdale's Toothbrushing in $\begin{array}{llll}\text { Schools } & \text { scheme. } & \text { 2013;22. } & \text { Available }\end{array}$ https://www.nice.org.uk/media/default/sharedlearning/797_toothbrushingevaluationreport_july2 013final.pdf

[8] MacNab A, Kasangaki A. "Many voices, one song": A model for an oral health programme as a first step in establishing a health promoting school. Health Promot Int. 2012;27(1):63-73.

[9] Ajzen I. The theory of planned behavior. Orgnizational Behav Hum Decis Process. 1991;50:179211.

[10] Glanz K, Rimer BK. Theory at a Glance: A Guide for Health Promotion Practice. The National 
Cancer Institute. 2005. 52 p

[11] Moshki M, Zamani-Alavijeh F, Mojadam M. Efficacy of Peer Education for Adopting Preventive Behaviors against Head Lice Infestation in Female Elementary School Students: A Randomised Controlled Trial. PLoS One [Internet]. 2017;12(1):e0169361. Available from: http://www.ncbi.nlm.nih.gov/pubmed/28072852\%0Ahttp://dx.plos.org/10.1371/journal.pone.016 9361

[12] Glanz, Karen V. Health Behavior and Health Education. Health Behaviour and Health Education. Theory, Research, and Practice. San Fransisco; 2008. 67-96 p.

[13] Rogéria A, Castilho F De, Luiz F, Souza T De, Puppin-rontani RM. Influence of family environment on children 's oral health : a systematic review. J Pediatr (Rio J). 2013;89(2):11623.

[14] Dallas S, Li J, Kruse K, Karen M-H. A Literature Review on Oral Health in Preschoolers [Internet]. Health Promotion Agency. 2015. 1-52 p. Available from: http://www.hpa.org.nz/sites/default/files/Literature review oral health.pdf

[15] Kadek Ayu Erika EN. Pengaruh Pendekatan Child Healthcare Model dan Transtheoretical Model terhadap Asupan Makan Anak Overweight dan Obesitas The Effect of Child Healthcare Model and Transtheoretical Model Approaches to Food Intake of Overweight and Obese Children. J Kesehat Masy Nas [Internet]. Elsevier Ltd; 2014;9(1):14-8. Available from: http://dx.doi.org/10.1016/j.jhealeco.2015.11.004

[16] Naim A, Setiawan A, Cahyono BA, Handiyatmo D, Susilo D, Handayani PS, et al. Profil Anak $\begin{array}{llllll}\text { Indonesia } 2015 & \text { [Internet]. 2015. } 246 & \text { p. Available from: }\end{array}$ http://www.kemenpppa.go.id/v3/index.php/daftar-buku/profilanak?download=510:profilanak2012

[17] Caan W, Cassidy J, Coverdale G, Ha M, Nicholson W. The value of using schools as community assets for health. 2014;9.

[18] Deinzer R, Cordes O, Weber J, Hassebrauck L, Weik U, Krämer N, et al. Toothbrushing behavior in children - an observational study of toothbrushing performance in 12 year olds. BMC Oral Health; 2019;1-9.

[19] Parmar P, Radha G, Pallavi S, Nagashree S. Promoting oral hygiene and health through school. Int J Oral Heal Sci. 2016;6(70):7.

[20] Thomas ER, Hall M, Owens J, Yesudian G, Hall M, Owens J, et al. Behavioral Health Promotion and Intervention in Intellectual and Developmental Disabilities. J Am Dent Assoc [Internet]. Association for Dental Sciences of The Republic of China; 2011;143(5):229-35. Available from: http://dx.doi.org/10.1016/S1991-7902(10)60012-8

[21] I Made Rustika. Efikasi Diri: Tinjauan Teori Albert Bandura. Bul Psikol FakPsikologi Univ Gadjahmada. 2012;20(1):18-25.

[22] Arianto A, Shaluhiyah Z. Perilaku Menggosok Gigi pada Siswa Sekolah Dasar Kelas V dan VI di Kecamatan Sumberejo. J Promosi Kesehat Indones Vol 9 / No 2 / Agustus 2014 [Internet]. 2016;9(Agustus 2014):127-35. Available from: http:// www.ejournal.undip.ac.id/ index.php /jpki/ article/ view/ 12728

[23] Sampakang T, Gunawan P. Status Kebersihan Mulut Anak Usia 9-11 Tahun Dan Kebiasaan Menyikat Gigi Malam Sebelum Tidur Di Sdn Melonguane. e-GIGI [Internet]. 2015;3:1-6. Available from: http://ejournal.unsrat.ac.id/index.php/egigi/article/view/6406

[24] Gigi K, Dasar S. Jurnal Ilmu Dan Teknologi Kesehatan Efikasi Kartu Senyum Berpengaruh terhadap Peningkatkan Derajat Artikel history. 2018;6(1).

[25] Bandura A. Health Promotion from the Perspective of Social Cognitive Theory. (1998):623-49.

[26] Doichinova L, Bakardjiev P, Peneva M. Assessment of food habits in children aged 612 years and the risk of caries. Biotechnol Biotechnol Equip [Internet]. Taylor \& Francis; 2015;29(1):200-4. Available from: http://dx.doi.org/10.1080/13102818.2014.989180

[27] Arrow P, Raheb J, Miller M. Brief oral health promotion intervention among parents of young children to reduce early childhood dental decay. BMC Public Health [Internet]. BMC Public Health; 2013;13(1):245. Available from: http://www.pubmedcentral.nih.gov/articlerender.fcgi?artid=3610190\&tool=pmcentrez\&renderty 
pe $=$ abstract

[28] Made D, Ambari D, Hutomo LC, Wayan L, Rahaswanti A, Studi P, et al. Gambaran perilaku menggosok gigi terhadap kejadian karies gigi pada anak usia sekolah dasar di wilayah kerja puskesmas sidemen, kecamatan sidemen, kabupaten karangasem, pada juni-juli 2013. 2013; 